Robert Kaczorowski ${ }^{1}$

Stanislaw Moniuszko Academy of Music in Gdansk, Gdansk, Poland

Department of Vocal Studies

\title{
"Confession Seals the Mouth" The cult of St. John of Nepomuk - a Martyr of the Sacramental Mystery - on the Example of 15 Songs from the Collection of Catholic Devotional Hymns for Church and Home Use, Published in Pelplin in 1871 Selected Theological and Musical Issues
}

\section{Introduction}

St. John of Nepomuk was born in 1348 in Pomuk (the name was later changed to Nepomuk) near Prague. In 1380 he was ordained a priest and became a pastor in the parish of St. Gall in Prague. He studied law at the universities of Prague and Padua. Acting as a mediator in the dispute between King Wenceslaus IV and the Archbishop of Prague, he was imprisoned and tortured, and then thrown from the Charles IV Bridge to the Vltava River. It took place on March 20, 13932.

Later legends add that "the priest was tied with a millstone around his neck and that the stone broke off; that the unusual brightness had awakened the people of Prague; that the king, seeing people's agitation, repented"3. However, according to the "Chronicle" of Thomas of Haselbach from 1450, the death of John

\footnotetext{
${ }^{1}$ Rev. Robert Kaczorowski - PhD. in Music Arts, assistant professor at the Department of Vocal Studies at the ocal and Acting Department of the Stanislaw Moniuszko's Academy of Music in Gdansk, parish priest of the parish of St. Nicholas in Szemud, email: r.kaczorowski@amuz.gda. pl. ORCID: 0000-0002-8228-6801.

${ }^{2}$ Internetowa Liturgia Godzin. Czytelnia. 21 maja. Święty Jan Nepomucen, prezbiter i męczennik, https://www.brewiarz.pl/czytelnia/swieci/05-21a.php3 [accessed 12.01.2021].

3 Ibidem.
} 
was caused by the fact that the priest did not reveal the secret of Queen Sophia's confession $^{4}$. The cult of the holy martyr spread quickly. In 1720 the Pope confirmed his beatification, and in 1729 St. John was declared a Saint ${ }^{5}$.

At that time, there were liturgical texts approved by the Holy See in honor of the Saint, including in Poland, where his cult was becoming more and more popular ${ }^{6}$.

This context contains the issue of this study, the aim of which is to show the special presence of St. John of Nepomuk in the piety of Poles, on the example of 15 songs from the Collection of Catholic Devotional Hymns for Church and Home Use, published in Pelplin in 1871.

In order to achieve the goal outlined above, the article will take the following steps. At the beginning, the source material will be presented, i.e. the Collection of Catholic Devotional Hymns for Church and Home Use, as well as the section with songs in honor of St. John of Nepomuk. Then, selected theological issues raised in the texts of the songs will be discussed, as well as some musical issues since the melodies were composed for several songs and they were undoubtedly used during the liturgy in churches. At the end, the most important conclusions will also be drawn, which will highlight the source of the popularity of St. John of Nepomuk among Poles.

In addition, it is worth paying attention to the topicality of the problem discussed in this article. St. John of Nepomuk was martyred because he had not revealed the secret of his confession. Nowadays, in various both in Polish and worldwide environments, where it is not understood what this sacrament is, theses appear more and more boldly that for important reasons a priest not only could, but also should, reveal the secret of confession. If he fails to do so, he will be in conflict with law and may be punished with imprisonment ${ }^{7}$. It is often forgotten, however, that as recorded in the text of Song I, "confession is sealed by the mouth"s.

${ }^{4}$ Ibidem.

${ }^{5}$ Ibidem.

${ }^{6}$ Ibidem.

7 See e.g. J. Mikulski, Australia chce znieść tajemnice spowiedzi, „Rzeczpospolita”, https:// www.rp.pl/Kosciol/170819422-Australia-chce-zniesc-tajemnice-spowiedzi.html [accessed 31.01. 2021]; J. Blikowska, Chca zniesienia tajemnicy spowiedzi, „Rzeczpospolita”, https://www.rp.pl/ artykul/1063397-Chca-zniesienia-tajemnicy-spowiedzi.html [accessed 31.01.2021]; Dakota Pótnocna zmusi kapłanów do ujawnienia tajemnicy spowiedzi?, ,Rzeczpospolita”, https://ekai.pl/dakota-polnocna-zmusi-kaplanow-do-ujawnienia-tajemnicy-spowiedzi/ [accessed 31.01.2021]; K. Ołdakowski, Prawo w Australii zobowiazuje do złamania tajemnicy spowiedzi, „Niedziela”, https://www. niedziela.pl/artykul/58033/Prawo-w-Australii-zobowiazuje-do-zlamania [accessed 31.01.2021].

${ }^{8}$ S. Keller, Zbiór pieśni nabożnych katolickich do użytku kościelnego i domowego, Pelplin 1871, p. 598. 


\section{Overview of the source material}

In 1871, Rev. Szczepan Keller prepared for printing and published in Pelplin a Collection of Catholic Devotional Hymns for Church and Home Use, which, on over 900 pages, contains over 1,100 songs for different periods of the liturgical year, for the Holy Trinity, for the Lord Jesus, the Blessed Virgin Mary, for the Holy Family, about Divine Providence, occasional songs, penitential songs, for the dead, about the ultimate things, morning and evening songs and many others. In addition, apart from the numbered ones, there are songs during the read Holy Mass, songs before and after the sermon, vespers and 42 Polish masses. In the "Songs of the Saints" section there are 15 songs "about St. John of Nepomuk ${ }^{10 "}$. Those are:

Song I, [incipit] Welcome, John of Boleslaw ${ }^{11}$,

Song II, [incipit] Being made famous by human tongues ${ }^{12}$,

Song III, [incipit] Happy Bohemia, which betrayed John ${ }^{13}$,

Song IV, [incipit] We praise you, Eternal Lord ${ }^{14}$,

Song V, [incipit] Saint John of Nepomuk ${ }^{15}$,

Song VI, [incipit] Nepomuk gives it out to the world ${ }^{16}$,

Song VII, [incipit] Quickly to the world you are announced ${ }^{17}$,

Song VIII, [incipit] Little May flower, dear ruby! ${ }^{18}$,

Song IX, [incipit] Jesus I call here ${ }^{19}$,

Song X, [incipit] We cry out to you ${ }^{20}$,

Song XI, [incipit] Famous with miracles, Nepomuk John ${ }^{21}$,

Song XII, [incipit] Saint John of Nepomuk, gloriously born ${ }^{22}$,

Song XIII, [incipit] Saint John of Nepomuk, for whom I cry heartily ${ }^{23}$,

Song XIV, [incipit] Invincible faith defender! ${ }^{24}$,

Song XV, [incipit] Saint John of Nepomuk! Thou be greeted $^{25}$.

9 Ibidem, pp. 557-733.

10 Ibidem, pp. 597-608.

${ }^{11}$ Ibidem. Song I is marked with No. 658, pp. 597-598.

${ }_{12}$ Ibidem. Song II is marked with No. 659, pp. 598-599.

${ }_{13}$ Ibidem. Song III is marked with No. 660, pp. 599-600.

${ }_{14}$ Ibidem. Song IV is marked with No. 661, pp. 600-601.

${ }^{15}$ Ibidem. Song V is marked with No. 662, p. 601.

${ }^{16}$ Ibidem. Song VI is marked with No. 663, pp. 601-602.

${ }^{17}$ Ibidem. Song VII is marked with No. 664, p. 602.

${ }_{18}$ Ibidem. Song VIII is marked with No. 665, pp. 602-603.

19 Ibidem. Song IX is marked with No. 666, pp. 603-604.

${ }^{20}$ Ibidem. Song X is marked with No. 667, p. 604.

${ }^{21}$ Ibidem. Song XI is marked with No. 668, pp. 604-605.

${ }^{22}$ Ibidem. Song XII is marked with No. 669, pp. 605-606.

${ }^{23}$ Ibidem. Song XIII is marked with No. 670, pp. 606-607.

${ }^{24}$ Ibidem. Song XIV is marked with No. 671, p. 607.

${ }^{25}$ Ibidem. Song XV is marked with No. 672, pp. 607-608. 
It is noteworthy that in the Collection..., for more than 220 works to various saints ${ }^{26}$, it is to St. John of Nepomuk that most of them were created (15). The second most popular saint turns out to be St. Joseph (11 songs $)^{27}$. However, among the Polish saints, the most songs are about St. Stanislaw, the Bishop and martyr $(8)^{28}$ and about St. Jan Kanty (5) ${ }^{29}$.

\section{Some theological issues put forward in the texts of the songs}

Out of 25 songs in honor of St. John of Nepomuk, the first four were qualified for "church use", which means that they could be performed during liturgical services celebrated in churches. The remaining 11 songs are for "home use" pieces, not intended for singing in churches. Their goal was the private cult of St. John. Therefore, "church" and "home" songs will be discussed separately.

\section{Songs to St. John of Nepomuk "for church use"}

Song I is a 20-stanza long rhyming story about these events in the life of St. John, which earned him fame, immortality and, above all, holiness. The author begins the song by greeting "John of Boleslaw", who, at the king's order, is to "appear" before him. John is "ready for anything"; is aware that visiting the king means "the hour of his death". Appearing before the monarch, John is asked about the sins of the king's wife admitted in confession. The priest replies that "he prefers to endure all torments rather than disclosing one word". After these words, the king orders John to be handed over to the executioners. The Saint is stripped of his garments and then "burned with torches and tar candles". John is aware that he endures all torments and tortures for the sake of Jesus Christ "and for his holy wounds". After the inflicted injuries, the martyred body with a tied stone is thrown into a nearby river.

The following verses of the song are a reflection of St. John over the seal of confession. He states therein that "confession is sealed by the mouth". It is therefore impossible to think, let alone talk to anyone about what you heard during this sacramental ministry. John knew that if he had broken the seal of confession, he would not have been martyred. The holy priest, however, persevered to the end, and he thanked for his death to the one who had given it to him.

John's death caused a great stir and "the poor orphans' weeping". That is why, people believed that their holy shepherd was immediately "transferred to

${ }^{26}$ Ibidem, pp. 557-733.

27 Ibidem, pp. 559-567.

28 Ibidem, pp. 582-589.

29 Ibidem, pp. 669-674. 
heaven". For John was a "teacher", "comforter", "doctor", the one who "gave alms" and "the holy almoner" for many. He died undeservedly. He was "drowned innocently" in defense of his holy faith. At the time of his death "the candle in the pulpit extinguished, the jewel in the crown was lost". Now, however, "he reigns with God in heaven, he intercedes for us there". From heaven's height, he is the "Patron" and "Famous Guardian".

Song II tells the story of a suffering, distressed man, exposed to gossip, slander and smear by his opponents. Such a life quickly became "unpleasant". The subject of the piece ensures that he has a "clear conscience". He also knows that "the slander thrown to besmirch the neighbors will hurt the slanderers themselves". He is aware of this, "because God punishes, but not betimes". That is why, he prays "for his slanderer", for those who wish him ill and who persecute him to come to their senses. He prays for their conversion. Only St. John of Nepomuk can save him from such "set snares". It is in him that he places all his hope. For St. John is the "Protector". He always comes to the help of those who ask for it.

In Song III, the homeland of St. John is called the "Happy Bohemia" because it was Bohemia that gave birth to the "holy priest" from "barren parents". He was a zealous preacher who had "God's zeal". He was the "Father" to the queen and her confessor. Later in the work, the saint's hassle with the monarch and the martyrdom of John by drowning "in Moldova" are recalled. When the martyr's body was placed in the cathedral, great miracles began to take place at his tomb: "God gives great gifts to men measurelessly". John is an "experienced Patron". Those who call upon his protection never fail.

Song IV becomes a thanksgiving to God for "he works miracles in Saint John". These signs appear not only in the "Czech Crown", but also Poland "recognizes him as a patron". The piece describes the youth of St. John, when he "grew in years both with his virtues, combining godliness with teachings", and as a priest he became "fierce with God's greater love". With the preached word he converted sinners, "confirmed in the virtues of saints by examples". Enjoying such fame, he soon became the Queen's confessor. After his martyrdom, "every day God adorns [the tomb of St. John] with miracles, and the holy Patron intercedes for us" in order to imitate his virtues and "avoid man's slanders".

\section{Songs to St. John of Nepomuk "for home use"}

Some "home" songs are reminiscent of the facts of the life of the holy martyr (Songs X, XII, XIV, XV) and the authority he enjoyed among the people. As a priest, he "raised all his love to heaven so that God may be praised" (Song VI). The great influence of the sermons and teachings of St. John, who called "the people to improve life" with "words and deeds" (Song VI) is emphasized. The people, moreover, "praise God by your speeches, moved by the prayers" 
(Song VII). The lyrics of the song point out that St. John was "the compassionate father of the poor" and the "caring shepherd" (Song XIV). Keeping the seal of confession, he "did not reveal the secret" (Song VI), and was therefore "pushed off the bridge" (Song VII).

After the martyr's death, St. John has been called "The Martyr of Prague" (Song V), "The Ornament of Prague Castle" (Song XII) and "The Light of the Prague Church" (Song XV). St. John is "a saintly canon" (Song V) and "a famous canon" (Song XII), "defender of the holy faith" (Song V) and "the invincible defender of faith" (Song XIV). The Czech martyr is a "zealous preacher" (Song XII) and "holy righteous preacher" (Song XV), "faithful confessor" (Song XII), "faithful to God confessor" (Song V), "mirror of confession" (Song XV) and "Virtues of silence's constant friend" (Song XIV). The example of St. John shows that "in every state, one may find one day to dwell in a heavenly land in Jesus' womb" (Song VIII).

St. John of Nepomuk as "God's faithful lover" (Song V) and "the man of God" (Song XIV) after his martyr's death, "reigns in heaven" and "reigns with Jesus in glory" (Song V). In his life "adorned with virtues" (Song VI), now "these virtues in heaven glorify the soul" (Song XIV).

Miracles are performed "every day" at his tomb (Songs VI, XIV), the fame of which spreads "throughout the world" (Songs V, VI). God makes these miraculous interventions through the intercession of St. John (Song XV). The miraculous signs "are proclaimed everywhere" (Song XII).

St. John is "the patron of human cause" (Songs V, X), "the patron in need" (Song XIV), and "the patron of great sinners" (Song IX). It is he who "saves the needy with holy prayers" (Song VII) and intercedes for them with God (Songs IX, XI, XII). Anyone who asks St. John for help, is heard (Song VI). That is why, people come to him with their affairs, sorrows and misfortunes. They plead with him for help in plight, distress and difficulties (Songs V, X, XIII). Requests to St. John of Nepomuk are diverse. People ask him to be like him "that all might live their lives in purity and love for others" (Song VIII), so that St. John taught them "for the benefit of speaking and the secret of silence" (Songs V, XIV); so that he would defend "from dishonor" (Songs VI, XIV, XV), "from infamy" (Song X), from "evil men's laughter" (Song XIV). In other prayers, the intention is expressed that St. John had people in his defense (Song VI), to "protect" and "save" (Song IX), to defend (Song X) and to lead (Song XII). That he would teach the truth (Song XV), help to "put away lies" and "slander" (Song XV), that he would remove "dishonest thoughts", "vain thoughts, all imperfections" (Song XV), and help to confess sins honestly in confession and "prompt the heart to repentance" (Song XV).

People also ask St. John so that they may die "in grace" (Song XIII) and so that their patron saint accompanies them "in the last death" (Song XI); so that 
they may receive eternal life (Songs V, XV), "absolution of sins and then salvation" (Song X).

Song XI is interesting, in which the author - in the context of requests made - mentions various misfortunes and diseases that St. John of Nepomuk helps to overcome. The text of the song states that the intercession of the holy martyr is recalled "in the fires" and during the "plague". Moreover, the saint helps "the lame and the blind" who recuperate, "the barren and sad", "those who are in fevers", and "receive help in the pregnancies of women". Moreover, St. John of Nepomuk helps during hunger, flood and other "water storms". He is the "helper" to the orphans, the "wandering guide", he helps "in poverty"; he is also a "helper" for orphans and consolation for "the despairing".

However, in Song VIII St. John is called the "Polish Patron". He is asked to intercede "for us", Poles, he is asked to be "a veil by God's throne" in situations "when sin has multiplied". They ask that, through the intercession of the holy priest, "famine, plague and war" and "crop infertility and fire" never come upon their land. Poles pray to St. John for the grace of conversion, that he may be "the protector of the widows, the protector of the orphans, the consolation for the poor" and that he may lead everyone to "eternal joy".

\section{Selected musical issues}

Simultaneously with the publication of the Collection of Catholic Devotional Hymns for Church and Home Use by pr. Szczepan Keller, two other priests: Józef Mazurowski and Teodor Kiewicz, also in 1871 published Melodies for a Collection of Devotional Songs (...). Composed for playing the organ and singing for four voices, in which there are three melodies of the song to St. John of Nepomuk. And so:

Song I (No. 658) has its own melody in G major. The piece is not divided into bars; four sections were distinguished, reflecting the division of lines in each stanza. Ambitus of the highest voice (melody line): $f i s^{l}-c^{230}$.

Song II (No. 659) also has its own melody in G major. This song is also not divided into bars; only the sections separating the individual lines of the stanza were parted. Ambitus of the highest voice (melody line): $f i s^{l}-d^{231}$.

Song III (No 660) has its own melody in the key of F major. There are also no bars in this song, but there are separate melodic sections in harmony with the rhythm of the poetic text. Ambitus of the highest voice (melody line): $f^{1}-d^{232}$.

${ }^{30}$ See Melodje do zbioru pieśni nabożnych katolickich dla użytku kościelnego. Utożone do grania na organach i śpiewania na cztery głosy, Pelplin 1871, p. 223.

31 Ibidem.

${ }^{32}$ Ibidem, p. 224. 
Song IV (No. 661) has no melody on its own. The publishers suggest singing it to the melody of one of the following: "Oh Saint Stanislaw, Bishop and Martyr", beginning with the words: Praise to you, our country's Patron! ${ }^{33}$.

The remaining songs (V-XV, No. 662-672) were classified by the publishers of Melodies... as domestic songs. For this reason, their notes are not included in the songbook ${ }^{34}$.

For an example of harmonization, it is helpful to read Song II, which begins with the words Being made famous by human tongues.

\section{Music example 1. Song II}

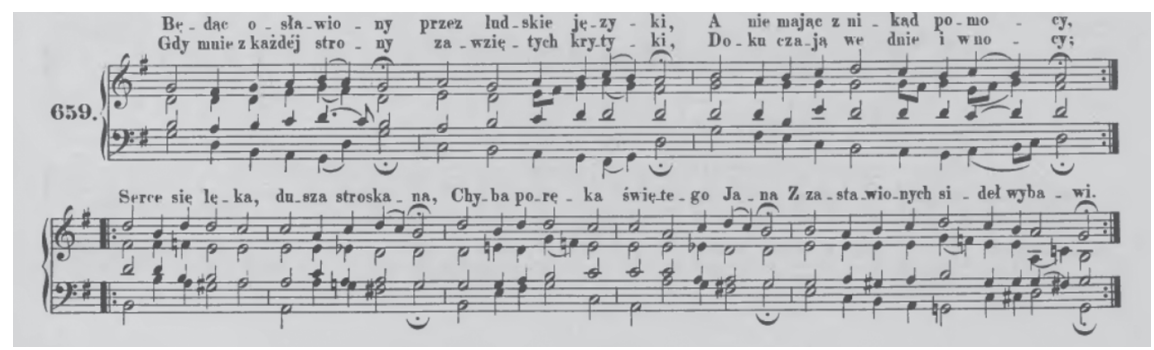

Source: Melodies for a Collection of Devotional Songs for Church Use. Composed for playing the organ and singing for four voices, Pelplin 1871, p. 223.

By using modern symbols of functional harmony ${ }^{35}$, Song II can be presented as follows:

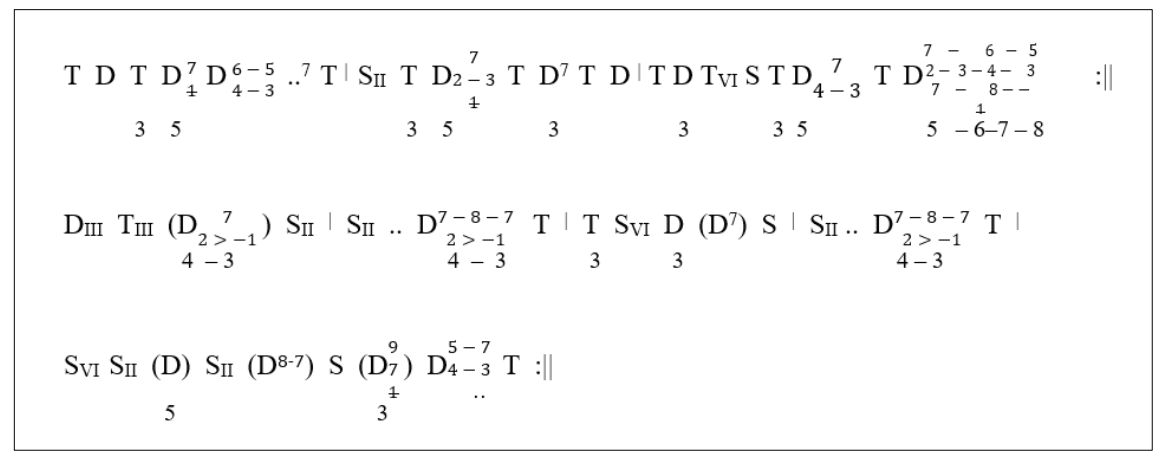

The harmonization of this song shows that the author who prepared it consistently uses the accepted principles resulting from the science of harmony. Still, the contrapuntal leading of the voices is visible.

${ }^{33}$ Ibidem. The song Cześć tobie, naszej krainy Patronie! can be found on p. 222 (No. 649).

${ }^{34}$ Ibidem, p. 224.

${ }^{35}$ See A. Poszowski, Harmonia tonalna, Gdańsk 1980. 
The following phenomena deserve attention:

- the first system, the first section, in the last seventh dominant (dominant seventh chord), the leading note fis $^{1}$ is treated freely - carried away by a jump (major third) down to the fifth of the tonic

- the first system, second section, in the first seventh dominant, the seventh is treated freely and carried away by a major second upwards

- the first system, the third section, in the second chord (dominant), the third in the lowest voice has not been resolved, and has moved down one major second to the root of $\mathrm{T}_{\mathrm{VI}}$ (nota bene with a doubled fifth)

- the first system, the third section, the seventh was doubled in the final chord of the dominant; both components are then discharged in the opposite direction. This section, and at the same time the first part of the song, ends with a cadence suspended on the dominant

- the second system, the second section, the fourth section and the fifth section - in these $S_{\text {II }}$ places (A minor chord) the root notes (not thirds) are doubled

- the second system, the fifth section, in the seventh dominant inserted into the subdominant, the sound $h^{l}$ was treated freely and carried away in a downward major third.

The above-mentioned harmonic phenomena can also be seen in modern harmony. However, they were articulated in order to show a certain consistency in the application of the principles of harmony by the creators of Melodies...

\section{Conclusions}

Description of 15 songs in honor of St. John of Nepomuk, coming from the Collection of Catholic Devotional Hymns for Church and Home Use, authorizes the formulation of several important conclusions:

- as a peculiar phenomenon, the existence of as many as 15 songs in honor of the Czech saint martyr in the Polish Collection of Catholic Devotional Hymns... as presented in the article; just a few songs were devoted to even the most popular Polish saint (most to St. Stanislaw, Bishop and martyr 8 and St. Jan Kanty - 5; even fewer songs were devoted to other Polish saints, respectively)

- the existence of 15 songs to St. John of Nepomuk proves that the saint was known and popular both in pre-partition Poland and later, during the partitions, in Polish lands. It can rightly be assumed that, in parallel with the 
knowledge of the life and work of St. John, the cult of the Saint also developed more and more, which is reflected in the songs discussed and many other devotional prayers that were created at that time

- undoubtedly, the Jesuit Order, for whom the priest-martyr is one of the main patrons, played a significant role in getting familiar with St. John of Nepomuk and reviving the cult of saints. Probably it is their merit that the cult of St. John became more and more popular in Poland as well from the neighboring Czech Republic, through Silesia

- the popularity of the cult of St. John of Nepomuk was certainly influenced by his conflict with the ruler, King Wenceslaus IV, as a result of which the priest was martyred. This story became close to Poles through the similarity with the events that took place over 300 years earlier in their lands, with the participation of St. Stanislaw the Bishop. This priest, admonishing King Boleslaw for bad treatment of his people and for publicly sowing scandal, also fell into conflict with him, as a result of which he was martyred as well

- both Saints enjoyed unquestionable authority, moral integrity and personal holiness during their lifetime. Death inflicted by the hands of the disliked and cruel rulers clearly contributed to the spread of the cult of holy priests-martyrs

- the cult of St. John of Nepomuk was also known in the Universal Church. This is evidenced by mentioning the Catholic Catechism published at the beginning of the $20^{\text {th }}$ century by Cardinal Pietro Gasparri, who, in the part devoted to the sacrament of confession and keeping its secret, wrote as follows:

The church, guarding the sanctity of this sacrament, pursues any violation of the sacramental seal of confession with the most severe penalties established in the Code of Canon Law. History knows about many of our priests who did not reveal the seal of confession, despite the fact that they suffered the cruelest torments and even died for it; let everyone have John of Nepomuk as an example, who, in defense of the seal of confession, was martyred in 1382 (sic!) and was recognized as one of the Saints $^{36}$

- St. John of Nepomuk, known for his miraculous interventions in various life situations described in songs, was invoked during confession, in danger of drowning and flooding, and even drought. A still living testimony to the cult of St. John are nepomuks, meaning figures of the saint, have been erected for centuries at crossroads and partings of the ways, at bridges and rivers. Until

${ }^{36}$ P. Gasparri, Katechizm Katolicki, Warszawa 2015, p. 194. The citation referred to is in a footnote marked with an asterisk. It incorrectly gives the year of the Saint's death. 
today, numerous examples of nepomukes can also be found in Poland. Moreover, almost 30 years ago the Nepomuk Brotherhood was established, whose mission is to find and "catalog all Nepomuk objects in Poland" and abroad ${ }^{37}$.

\section{Summary}

In the presented article, the author discusses 15 songs composed in honor of St. John of Nepomuk, coming from the Collection of Catholic Devotional Hymns for Church and Home Use, published in 1871 in Pelplin. The number of songs proves that the cult of St. John was widespread among Polish people. This Saint enjoyed extraordinary authority because he remained faithful to his priestly vocation until his martyrdom. He preferred to die than to reveal the secret of the holy confession. Thus, St. John of Nepomuk remains the Patron Saint of Confessors until this day.

Keywords

St. John of Nepomuk, religious song, confession, mystery

\section{„Spowiedź usta pieczętuje”. Kult św. Jana Nepomucena - męczennika sakramentalnej tajemnicy, na przykładzie 15 pieśni pochodzących ze Zbioru pieśni nabożnych katolickich do użytku kościelnego i domowego, opublikowanego w Pelplinie w 1871 roku. Wybrane zagadnienia teologiczne i muzyczne}

\section{Streszczenie}

W prezentowanym artykule autor omawia 15 pieśni ku czci św. Jana Nepomucena, pochodzących ze Zbioru pieśni nabożnych katolickich do użytku kościelnego i domowego, opublikowanych w 1871 roku w Pelplinie. Liczba pieśni świadczy o tym, że kult św. Jana Nepomucena był rozpowszechniony wśród Polaków. Święty ten cieszył się niezwykłym autorytetem wynikającym z faktu, że pozostał wierny powołaniu kapłańskiemu aż do śmierci męczeńskiej. Wolał zginąć niż wyjawić tajemnicę spowiedzi świętej. Dlatego też św. Jan Nepomucen do dzisiaj pozostaje patronem spowiedników.

\section{Słowa kluczowe}

Święty Jan Nepomucen, pieśń religijna, spowiedź święta, tajemnica

${ }^{37}$ Bractwo Nepomuckie. Serwis nepomucki, http://nepomuki.pl/nepomuk/index.html [accessed 16.01.2021]. 


\section{Bibliography}

Blikowska J., Chca zniesienia tajemnicy spowiedzi, ,Rzeczpospolita”, https://www.rp.pl/ artykul/1063397-Chca-zniesienia-tajemnicy-spowiedzi.html [accessed 31.01.2021].

Bractwo Nepomuckie. Serwis nepomucki, http://nepomuki.pl/nepomuk/index.html [accessed 16.01.2021].

Dakota Pólnocna zmusi kapłanów do ujawnienia tajemnicy spowiedzi?, „Rzeczpospolita", https://ekai.pl/dakota-polnocna-zmusi-kaplanow-do-ujawnienia-tajemnicy-spowiedzi/ [accessed 31.01.2021].

Gasparri P., Katechizm Katolicki, Warszawa 2015.

Internetowa Liturgia Godzin. Czytelnia. 21 maja. Święty Jan Nepomucen, prezbiter i męczennik, https://www.brewiarz.pl/czytelnia/swieci/05-21a.php3 [accessed 12.01. 2021].

Keller S., Zbiór pieśni nabożnych katolickich do użytku kościelnego i domowego, Pelplin 1871.

Mazurowski J., Kiewicz T., Melodje do zbioru pieśni nabożnych katolickich dla użytku kościelnego. Ułożone do grania na organach i śpiewania na cztery głosy, Pelplin 1871 .

Mikulski J., Australia chce znieść tajemnice spowiedzi, „Rzeczpospolita”, https://www. rp.pl/Kosciol/170819422-Australia-chce-zniesc-tajemnice-spowiedzi.html [accessed 31.01.2021].

Ołdakowski K., Prawo w Australii zobowiąuje do złamania tajemnicy spowiedzi, „Niedziela", https://www.niedziela.pl/artykul/58033/Prawo-w-Australii-zobowiazuje-do-zlamania [accessed 31.01.2021].

Poszowski A., Harmonia tonalna, Gdańsk 1980. 